\title{
Eco-friendly surfactants in glyphosate formulation
}

\author{
Tensoativos ecológicos na formulação de glifosato
}

\author{
Romina C. Pessagno ${ }^{123^{*}}$ (ORCID 0000-0003-2265-4681), Diego Grassi ${ }^{123}$ (ORCID 0000-0002-4702-4064), Camila Pedraza1, \\ Gustavo Thompson ${ }^{3}$ (ORCID 0000-0002-5511-3673), Carlos Ojeda ${ }^{123}$ (ORCID 0000-0003-3995-1105)
}

\author{
${ }^{1}$ Universidad de Buenos Aires. Facultad de Ciencias Veterinarias. Cátedra Química Orgánica de Biomoléculas. Buenos Aires, \\ Argentina. *Author for correspondence: rpessagno@fvet.uba.ar \\ ${ }^{2}$ Universidad de Buenos Aires. Centro de Estudios Transdisciplinarios del Agua (CETA). Buenos Aires, Argentina. \\ ${ }^{3}$ CONICET-Universidad de Buenos Aires. Instituto de Investigaciones en Producción Animal (INPA). Buenos Aires. Argentina.
}

Submission: 21/04/2021 | Acceptance: 16/08/2021

\begin{abstract}
Weeds affect various crops worldwide, causing low yields and, therefore, significant economic losses. These losses can be minimized by the use of herbicides such as glyphosate. However, the efficiency of glyphosate depends on the type of agrochemical formulations. The most widely used surfactant is polyethoxylated tallow amine. Nevertheless, the disadvantage of these compounds is that their toxicity is greater than that of glyphosate itself. Thus, this study aimed to develop an environmentally-friendly combination of surfactants that can increase the performance of glyphosate compared to other currently used formulations. Saponin (S) is environmentally friendly and has a unique ability to go through the waxy cuticle of the weed leaf. However, its interfacial properties are very poor. In contrast, the alkyl glucoside (AG) mixture has shown excellent interfacial properties, being an environmentally safe surfactant, but cannot pass through the cuticle. In the present study, we mixed both surfactants. Two formulations were made with $20 \%$ (F1) and $2 \%$ (F2) of S with $4 \%$ AG. To verify the usefulness of our formulations, they were compared against a commercial product. The results showed that the commercial product had better CMC $0.3 \pm 0.1 \%$ and $\mathrm{pC}_{20} 1.155 \pm 0.099$ than our formulations $\mathrm{F} 1$ and $\mathrm{F} 2$. Formulations $\mathrm{F} 1$ and $\mathrm{F} 2$ showed better $\gamma \mathrm{CMC}$ than the commercial product $36.5 \pm 4.1 \mathrm{mN} / \mathrm{m}$ and $30.9 \pm 1.4 \mathrm{mN} / \mathrm{m}$, respectively. Field tests showed that F2 was more effective than the commercial product in eliminating weeds at the end of the test at 30 days. Our results allowed confirming that the use of saponin improves the efficiency of glyphosate. The work showed that structures similar to cyclopentaneperhydrophenanthrene are very effective for introducing drugs into plants through the leaves. This is an advance in general and in particular for the increase of the yield in certain crops.
\end{abstract}

KEYWORDS: saponin, weed, herbicide, surfactants, efficiency.

\section{RESUMO}

As ervas daninhas afetam várias culturas em todo o mundo, causando baixos rendimentos e perdas econômicas significativas. Essas perdas podem ser minimizadas pelo uso de herbicidas como o glifosato, cuja eficiência depende do tipo de formulação agroquímica. O surfactante mais amplamente utilizado é a amina de sebo polietoxilada. No entanto, a desvantagem desses compostos é que sua toxicidade é maior do que a do próprio glifosato. Este estudo teve como objetivo desenvolver uma combinação de surfactantes ecologicamente correta que pode aumentar o desempenho do glifosato em comparação com outras formulações utilizadas atualmente. A saponina (S) é ecologicamente correta e tem a capacidade única de atravessar a cutícula cerosa da folha da erva daninha. No entanto, suas propriedades interfaciais são muito pobres. Em contraste, a mistura de alquil glicosídeo (AG) apresentou excelentes propriedades interfaciais, sendo um surfactante ambientalmente seguro, mas não pode passar pela cutícula. No presente estudo, misturamos os dois surfactantes. Duas formulações foram feitas com $20 \%$ (F1) e $2 \%$ (F2) de S com 4\% AG. Para verificar a utilidade das nossas formulações, elas foram comparadas com um produto comercial. Os resultados mostraram que o produto comercial apresentou melhor $\mathrm{CMC} 0,3 \pm 0,1 \% \mathrm{e}$ pC20 1,155 $\pm 0,099$ do que nossas formulações F1 e F2. As formulações F1 e F2 mostraram $\gamma C M C$ melhor do que o produto comercial $36,5 \pm 4,1 \mathrm{mN} / \mathrm{m}$ e $30,9 \pm 1,4 \mathrm{mN} / \mathrm{m}$, respectivamente. Os testes de campo mostraram que o $\mathrm{F} 2$ foi mais eficaz do que o produto comercial na eliminação de ervas daninhas no final do teste aos 30 dias. Nossos resultados permitiram confirmar que o uso da saponina melhora a eficiência do glifosato. $\mathrm{O}$ trabalho mostrou que estruturas semelhantes ao ciclopentanoperidrofenantreno são muito 
eficazes para a introdução de drogas nas plantas através das folhas. Este é um avanço em geral e, em particular, para o aumento da produtividade de certas safras.

PALAVRAS-CHAVE: saponina, erva daninha, herbicida, surfactantes, eficiência.

\section{INTRODUCTION}

Modern agricultural systems demand the reduction of economic losses caused by both abiotic and biotic factors. Among biotic factors, weeds are considered the most harmful (GHARDE et al. 2018). In this context, glyphosate-based herbicides are of enormous importance for farmers to make strategic decisions to reduce the economic losses due to weeds. Furthermore, due to its efficiency, farmers prefer the use of glyphosate to other alternatives, especially in large-scale fields (DANNE et al. 2019).

Since glyphosate is a systemic herbicide, its agrochemical formulations always use a surfactant to stimulate foliar absorption by moistening the leaf surface, slowing down evaporation and finally improving cuticle penetration for a better translocation (CASTRO et al. 2014, HAOJING et al. 2016, MESNAGE 2021). Most glyphosate-based herbicides use non-ionic surfactants, among which the most widely used are polyethoxylated tallow amine [or polyoxyethylene amine (POEA)]. However, these compounds have become controversial due to their negative impact on the environment (BEDSÁSOVÁ et al. 2020). Thus, numerous studies focus on the search for environmentally friendly biosurfactants obtained directly from renewable natural materials (WOJCIECHOWSKI 2013, MERINO \& ALVAREZ 2021). Among these natural products, saponins have high biodegradability and are safe for the environment. Besides, they can cross the waxy cuticle of the leaves of weeds, which is the target of systemic herbicides such as glyphosate (CHAPAGAIN \& WIESMAN 2006) and the main obstacle to the penetration of the different active principles of herbicides applied in the field. It consists of a hydrophobic epicuticular wax layer that must be crossed for the herbicide to reach living cells (CHAPAGAIN \& WIESMAN 2004). Due to their structure, saponins have already been used successfully as the surfactant of the herbicide 2,4-dichlorophenoxyacetic acid (2,4-D) (CHAPAGAIN \& WIESMAN 2006). On the other hand, since saponins are very safe for the environment, they are even being used to replace the well-known and widely used food additive Tween 80 in the food industry (RIQUELME et al. 2019). All this suggests that saponins could also facilitate the delivery of other active ingredients such as glyphosate.

In the present study, a mixture of saponin (S) and alkylglucosides (AG) was chosen to be tested as a surfactant for glyphosate formulations because it is environmentally friendly, has a unique ability to go through the waxy cuticle of the weed leaf and has good interfacial properties.

Based on the above, this study aimed to develop and test a new glyphosate formulation based on environmentally friendly biosurfactants as saponins, looking for a replacement to POEA surfactants.

\section{MATERIAL AND METHODS}

\section{Reagents}

The reagents used were: saponin (S) (SIGMA 84510), an alkyl glucoside mixture (AG) containing 40\% octylglucoside and $60 \%$ decyglucoside with a purity range of $68-72 \%$, the potassium salt of glyphosate (KG), technical grade glyphosate of $95 \%$ purity, and $\mathrm{KOH}$ of $85 \%$ purity. The concentration of glyphosate in KG was 540 grams acid equivalent per liter.

At the time of application, the vegetative stage was in the V4-V5 range as recommended by the commercial product (PERÉZ \& PÉREZ 2007-2008). The test was carried out in a natural environment. The experiments were conducted with a Sorghum halepense strain with no resistance to glyphosate, developed by the Department of Plant Production of the School of Agricultural Sciences of the University of Buenos Aires (Buenos Aires, Argentina). The weeds were sown in pots containing soil systematically used for this type of experiment. The soil consisted of peat, compost and perlite and was the same in all pots. The pH was between 6 and 6.5 , electrical conductivity was $0.20 \mathrm{mS} / \mathrm{cm}$, organic matter was $21.6 \%$, ash content was $78.4 \%$, dry density was $446 \mathrm{~g} / \mathrm{cm}^{3}$, and total porosity was $80.4 \%$.

\section{Formulations tested}

Formulations were made as follows. First, the potassium glyphosate salt was prepared at a concentration of $540 \mathrm{~g} / \mathrm{L}$. Then, in a container previously weighed, potassium hydroxide $(88 \%)$ and water were diluted. Subsequently, it was stirred until the total dissolution of the potassium hydroxide. Then glyphosate (95\%) was added in portions and with permanent stirring until it was completely dissolved. Finally, it was allowed to cool, and it was completed with water or solutions of saponin and / or alkylglucoside to comply with the concentrations of the different formulations presented in Table 1. 
The percentages of each surfactant tested in $\mathrm{F} 1$ and $\mathrm{F} 2$ were selected after several tests previously conducted at the laboratory. F1 and F2 were prepared at different concentrations to study how saponin concentration affects the herbicidal capacity. Formulations F3 and F4 showed that without good interfacial properties saponin is not enough. F5 showed that although the interfacial properties are good, saponin is necessary.

The active ingredient alone (Al) was tested to show that, without a surfactant, glyphosate has no effect, and the results are similar to those of the controls.

A total of seven formulations were tested: six of them were prepared by us, and one was a commercial

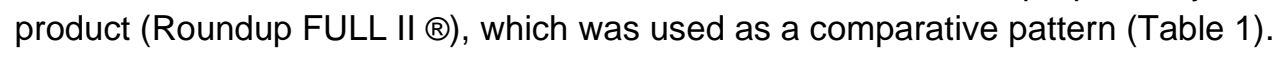

Table 1. Composition of the formulations tested.

\begin{tabular}{|l|l|l|l|}
\hline & S & AG & KG \\
\hline CP & no data & no data & 540 grams acid equivalent per liter \\
\hline F1 & $20 \%$ & $4 \%$ & 540 grams acid equivalent per liter \\
\hline F2 & $2 \%$ & $4 \%$ & 540 grams acid equivalent per liter \\
\hline F3 & $20 \%$ & --- & 540 grams acid equivalent per liter \\
\hline F4 & $2 \%$ & --- & 540 grams acid equivalent per liter \\
\hline F5 & --- & $4 \%$ & 540 grams acid equivalent per liter \\
\hline Al & --- & --- & 540 grams acid equivalent per liter \\
\hline
\end{tabular}

CP: Commercial product (Roundup FULL II $\AA$ ), used as a comparative pattern. This commercial product uses surfactant, but its composition is unknown. S: Saponin. AG: Alkyl glucoside. KG: Potassium salt of glyphosate. Al: Active ingredient alone.

\section{Application of the formulations}

The different formulations studied were applied by an operator with a backpack sprayer. The spray tip was a flat TeeJet ${ }^{\mathrm{TM}} 110015 \mathrm{VP}$ (green) with a $\mathrm{CO}_{2}$ sprayer with boom, $2 \mathrm{~m}$ of work width, and four nozzles. The speed was 7 meters in 5 seconds $(1.4 \mathrm{~m} / \mathrm{s}$ or $5.04 \mathrm{~km} / \mathrm{h})$, the delivery rate was $100 \mathrm{~L} / \mathrm{ha}$, and the application pressure was 40 psi $\times 2.7579$ bar. The applications were made at $10 \mathrm{am}$. At the time of application, the climatic conditions were temperature $28^{\circ} \mathrm{C}$, humidity $80 \%$ without wind.

Tap water from the City of Buenos Aires, whose quality allows it to be drinkable and whose physicochemical properties are shown in Table 2, was used to apply the formulations in the field experiments. The experiments were carried out between December 2017 and January 2018.

Table 2. Physicochemical parameters of the tap water used to apply the formulations tested.

\begin{tabular}{|c|c|c|c|c|c|c|}
\hline $\mathrm{pH}$ & $\begin{array}{c}\text { Conductivity } \\
(\mu \mathrm{S} / \mathrm{cm})\end{array}$ & $\begin{array}{c}\text { Alkalinity } \\
\left(\mathrm{mg} / \mathrm{L} \mathrm{CaCO}_{3}\right)\end{array}$ & $\begin{array}{c}\text { Total Hardness } \\
(\mathrm{mg} / \mathrm{L} \mathrm{CaCO})\end{array}$ & $\begin{array}{c}\text { Total Solids } \\
(\mathrm{mg} / \mathrm{L})\end{array}$ & $\begin{array}{c}\mathrm{Cl}^{-} \\
(\mathrm{mg} / \mathrm{L})\end{array}$ & $\begin{array}{c}\mathrm{NO}_{3}{ }^{-} \\
(\mathrm{mg} / \mathrm{L})\end{array}$ \\
\hline 7.62 & 545 & 102 & 52 & 364 & 50 & 3 \\
\hline
\end{tabular}

\section{Measurement of interfacial properties}

The following main interfacial properties of the formulations tested were analyzed to determine their efficiency. Air-water surface tensions $(\gamma)$ were measured at $25^{\circ} \mathrm{C}$ for different concentrations of the formulations in milli-Q water in a Traube stalagmometer (BUCHBERGER et al. 2018, JOVANOVIC et al. 2019, KLIJN \& HUBBUCH 2019) and then plotted versus log $C$ to obtain the critical micellar concentration $(C M C)$ of each formulation. The $C M C$, the critical surface tension $(\gamma C M C)$, and $\mathrm{pC}_{20}$ were determined for all formulations (FERLIN et al. 2008, FERLIN et al. 2010, FERLIN et al. 2015). $\gamma$ CMC is the surface tension of the formulation at the $\mathrm{CMC}$ and is the lowest value of surface tension that each formulation can reach. Therefore, it is a valuable measure to determine the effectiveness of the surfactant to reduce the surface tension of the solvent. The efficiency of a surfactant can also be measured by the $\mathrm{pC}_{20}$ value $\left(-\log \mathrm{C}_{20}\right)$, where $\mathrm{C}_{20}$ is the surfactant concentration in the aqueous phase required to decrease the surface tension of the solvent by $20 \mathrm{mN} \mathrm{m}^{-1}$. The $\mathrm{pC}_{20}$ value characterizes the efficiency of the surfactant to reduce the surface tension: a higher $\mathrm{pC}_{20}$ means that less surfactant is needed to reduce the surface tension.

Uncertainty in the interfacial properties. Statistical approach

The uncertainty in the CMC is determined by the intersection of confidence bands obtained for both regression straigth lines in the plot of surface tension vs. $\log (\mathrm{C})$. Horizontal projection of the intersections of 
the confidence bands are presented as dotted line Figure 1.

Figure 1. Calculation of CMC and its standard uncertainty at $95 \%$ confidence.

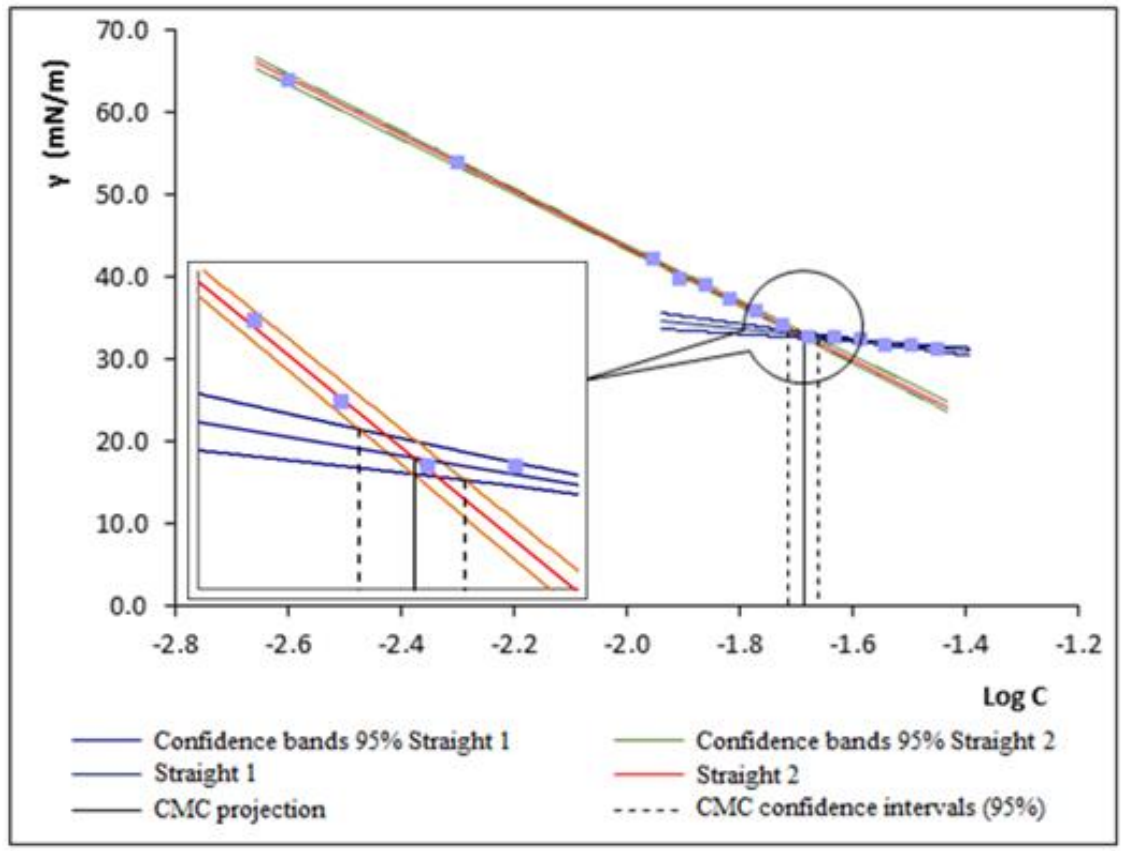

From the uncertainty in the $\mathrm{CMC}$, the uncertainty is propagated to the rest of the interfacial properties following the usual procedures (FERLIN et al. 2008, FERLIN et al. 2010, FERLIN et al. 2015).

\section{Experimental design}

Fifteen treatments were performed (Table 3). Treatment zero (T0) corresponds to untreated weeds used as controls. Treatments with equal numbers correspond to the same formulation but were applied at two different concentrations: low (L): $500 \mathrm{~mL} / \mathrm{ha}$ and high $(\mathrm{H}): 750 \mathrm{~mL} / \mathrm{ha}$. Each of the different treatments was applied in five pots, and each pot was planted with five plants. The final evaluation was made 30 days after the start of all treatments.

Table 3. Description of the selected treatments.

\begin{tabular}{|c|c|c|}
\hline Treatments & Amount applied & Formulation \\
\hline T0 & Zero & None \\
\hline $\mathrm{T} 1 \mathrm{H}$ & $750 \mathrm{~mL} / \mathrm{ha}$ & $\mathrm{CP}$ \\
\hline $\mathrm{T} 2 \mathrm{H}$ & $750 \mathrm{~mL} / \mathrm{ha}$ & $\mathrm{F} 1$ \\
\hline T3 H & $750 \mathrm{~mL} / \mathrm{ha}$ & $\mathrm{F} 2$ \\
\hline $\mathrm{T} 4 \mathrm{H}$ & $750 \mathrm{~mL} / \mathrm{ha}$ & F3 \\
\hline $\mathrm{T} 5 \mathrm{H}$ & $750 \mathrm{~mL} / \mathrm{ha}$ & $\mathrm{F} 4$ \\
\hline $\mathrm{T} 6 \mathrm{H}$ & $750 \mathrm{~mL} / \mathrm{ha}$ & F5 \\
\hline $\mathrm{T} 7 \mathrm{H}$ & $750 \mathrm{~mL} / \mathrm{ha}$ & $\mathrm{Al}$ \\
\hline T1 L & $500 \mathrm{~mL} / \mathrm{ha}$ & $\mathrm{CP}$ \\
\hline T2 L & $500 \mathrm{~mL} / \mathrm{ha}$ & $\mathrm{F} 1$ \\
\hline T3 L & $500 \mathrm{~mL} / \mathrm{ha}$ & $\mathrm{F} 2$ \\
\hline T4 L & $500 \mathrm{~mL} / \mathrm{ha}$ & F3 \\
\hline T5 L & $500 \mathrm{~mL} / \mathrm{ha}$ & $\mathrm{F} 4$ \\
\hline T6 L & $500 \mathrm{~mL} / \mathrm{ha}$ & F5 \\
\hline T7 L & $500 \mathrm{~mL} / \mathrm{ha}$ & $\mathrm{Al}$ \\
\hline
\end{tabular}

CP: Commercial product (Roundup FULL II ®). Al: Active ingredient alone. H: High concentration. L: Low concentration.

Plant survival was visually estimated for each plant. Survival ranged from 0 to $100 \%$ and was expressed by the number of live plants 30 days after each treatment over the total plants per pot. The 
survival status of the weeds was assessed by the same group of the School of Agricultural Sciences of the University of Buenos Aires that facilitated the Sorghum halepense strain used in this work. The formulations were coded so that the researchers were blinded to each treatment. This procedure was done to ensure independence, neutrality, and objectivity when assessing the results obtained in the field. The herbicidal effect of each formulation was compared against control plants (which received no application of any product). Figures 2 and 3 show how the field experiment was carried out.

Figure 2. Experiment at the time of application of the different formulations.

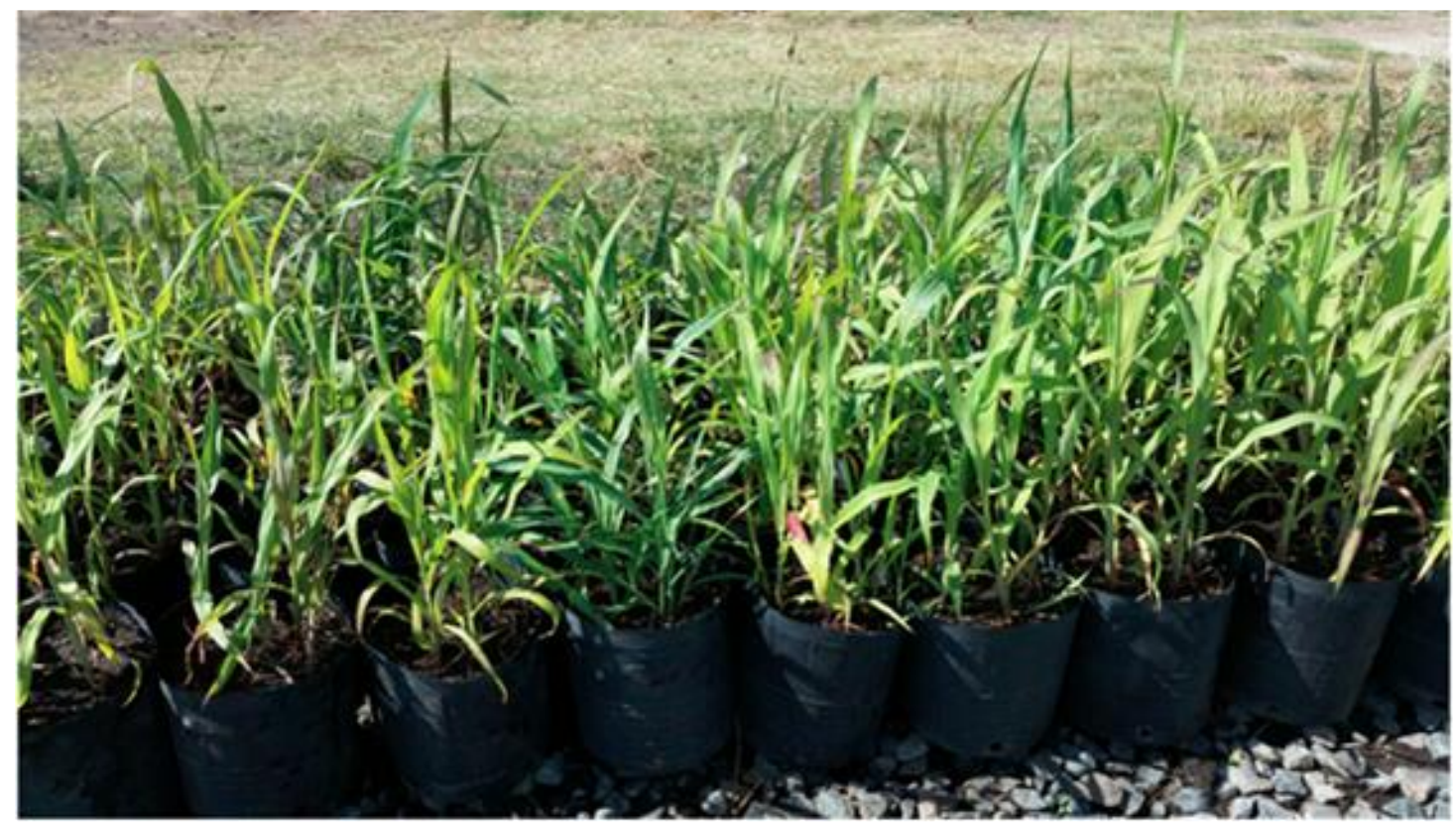

Figure 3. End of the experiment 30 days later.

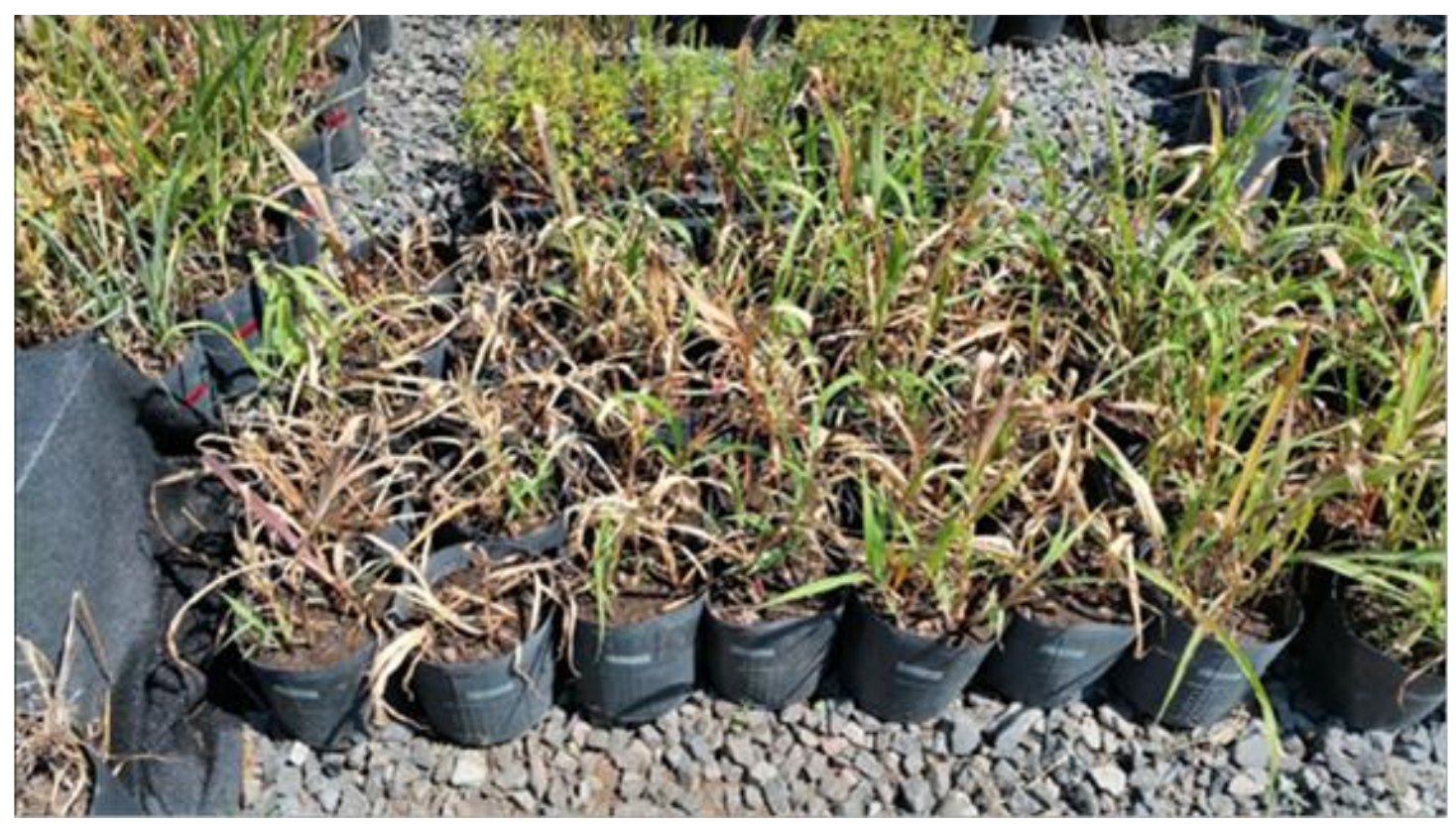

\section{Statistical design}

The survival rates of Sorghum halepense were compared among treatments [control (T0), commercial product (T1) and six experimental formulations (T2-T7)] and concentrations (low and high), by using a twoway ANOVA (ZAR 2010). After, a posteriori comparison by Dunnett's multiple comparison test was conducted to determine whether changes in the survival rate could be expected with different formulations when compared with the controls (ZAR 2010). Finally, a posteriori comparison was performed by Tukey's HSD test among formulations and the commercial product (ZAR 2010). There was no need to transform the survival rate data since assumptions of normality and homogeneity of variance were met (Infostat $\AA$; DI 
RIENZO et al. 2018).

\section{RESULTS AND DISCUSSION}

The outcomes of the three interfacial properties, namely critical micellar concentration, critical surface tension, and the efficiency of surfactant to reduce the surface tension (pC20), were analysed for the two surfactants, and the seven formulations tested were shown in Table 4 and Table 5, respectively.

The best values of interfacial properties (lower $\mathrm{CMC}$ and higher $\mathrm{pC}_{20}$ values) among all formulations tested were those of CP. However, the interfacial properties of formulations combining saponin and AG (F1 and F2) showed worse results than the $\mathrm{CP}$ (higher $\mathrm{CMC}$ and lower $\mathrm{pC}_{20}$ values; Table 5). This was due to the use of saponin, which, as shown in Table 4, has significantly higher $\mathrm{CMC}$ and lower $\mathrm{pC}_{20}$ values (worse interfacial properties) than AG.

The formulations without AG (F3 and F4) showed even worse interfacial properties than saponin (Tables 4 and 5). A possible explanation for this is that the combination with KG further diminishes saponin's already poor interfacial properties.

This explanation would be corroborated by the interfacial properties shown by F5 (Table 5). However, a remarkable fact that should be highlighted is that the association of saponin and AG would nullify the effect that worsens the interfacial properties when $K G$ is added to the formulation. This can be observed by comparing the values of the interfacial properties of F1, F2, F3, F4, and F5.

Table 4. Interfacial properties of the surfactants tested.

\begin{tabular}{|c|c|c|c|}
\hline Surfactants & $\begin{array}{c}\mathrm{CMC} \\
{[\mathrm{g} / 100 \mathrm{~g}]}\end{array}$ & $\begin{array}{r}\gamma \mathrm{CMC} \\
{[\mathrm{mN} / \mathrm{m}]}\end{array}$ & $\mathrm{pC}_{20}$ \\
\hline $\mathrm{S}$ & $5.6 \pm 1.3$ & $50.8 \pm 0.1$ & $-0.416 \pm 0.566$ \\
\hline $\mathrm{AG}$ & $0.3 \pm 0.1$ & $32.0 \pm 1.9$ & $1.444 \pm 0.111$ \\
\hline
\end{tabular}

S: Saponin. AG: Alkyl glucoside.

Table 5. Interfacial properties of the formulations tested.

\begin{tabular}{|c|c|c|c|}
\hline Formulations & $\begin{array}{c}\mathrm{CMC} \\
{[\mathrm{g} / 100 \mathrm{~g}]}\end{array}$ & $\begin{array}{c}\gamma \mathrm{CMC} \\
{[\mathrm{mN} / \mathrm{m}]}\end{array}$ & $\mathrm{pC}_{20}$ \\
\hline $\mathrm{CP}$ & $0.3 \pm 0.1$ & $41.8 \pm 0.3$ & $1.155 \pm 0.099$ \\
\hline $\mathrm{F} 1$ & $1.6 \pm 1.2$ & $36.5 \pm 4.1$ & $0.510 \pm 0.153$ \\
\hline $\mathrm{F} 2$ & $2.9 \pm 2.0$ & $30.9 \pm 1.4$ & $0.208 \pm 0.182$ \\
\hline F3 & $37.6 \pm 13.4$ & $45.0 \pm 1.2$ & $-0.730 \pm 0.162$ \\
\hline F4 & $26.7 \pm 27.6$ & $53.3 \pm 5.0$ & $-1.483 \pm 0.221$ \\
\hline F5 & $3.9 \pm 1.9$ & $30.3 \pm 4.3$ & $0.275 \pm 0.098$ \\
\hline Al & --- & --- & -- \\
\hline
\end{tabular}

CMC: Critical micellar concentration. $\gamma \mathrm{CMC}$ : Critical surface tension. $\mathrm{pC}_{20}$ : $-\log \mathrm{C}_{20}$. $\mathrm{C}_{20}$ : Surfactant concentration in the aqueous phase required to decrease the surface tension of the solvent by $20 \mathrm{mN} \mathrm{m}^{-1}$.

CP: Commercial product (Roundup FULL II $\AA^{\circledR}$ ). Al: Active ingredient alone.

The survival rate of Sorghum halepense was different between treatments and concentrations (ANOVA F F,64: 2.99 P:0.008 for 15 days measurement; Figure 4 and $F_{7,64}: 2.66$ P: 0.017 for 30 days measurement; Figure 5), being significantly lower (i.e. higher performance) for the high concentration of the experimental formulation T6 (Dunnett's test P:0.002) than for the control at 15 days measurement. In addition, survival was significantly lower for the high concentrations of the commercial product (T1) and experimental formulations T2, T3, T4 and T6 (Dunnett's test; $\mathrm{P}<0.004$ ) as well as for the low concentration of T2 (Dunnett's test; $P<0.011$ ) than for the control at 30 days measurement. On the other hand, comparison between all the experimental formulations (T2-T7) and the commercial product (T1) showed no significant differences (i.e. similar performance) between the commercial product and both low and high concentrations all of the experimental formulations (Tukey's HSD test $P>0.17$ ) at 15 days measurements. In addition, there were no significant differences (i.e. similar performance) between the commercial product and the high concentrations of the experimental formulations T2, T3, T4 and T6 (Tukey's HSD test; P>0.70) as well as between the commercial product and the low concentrations of all the experimental formulations (Tukey's HSD test $P>0.59$ ) at 30 days measurements. 
Saponins appear in the literature being used as an adjuvant in vaccines (MO et al. 2011, CORDEIRO GIUNCHETTI et al. 2019), adjuvant in genetic experiments (SMIT et al. 2021), precursor of pharmacological substances against neurodegenerative diseases (AYENI et al. 2021), liver protector (LINLIN et al. 2021) in addition to other uses. However, its use was not found in agrochemical formulations of glyphosate. Patent secrets limit the search for information on the components of an agrochemical.

Figure 4. Effect of the different formulations tested and concentrations of surfactants on the survival of Sorghum halepense ranged from 0 to $100 \%(1.0)$ at 15 days of measurement. $\left({ }^{*}\right)$ Denotes significant difference with the control (T0). Vertical bars denote $95 \%$ confidence intervals.

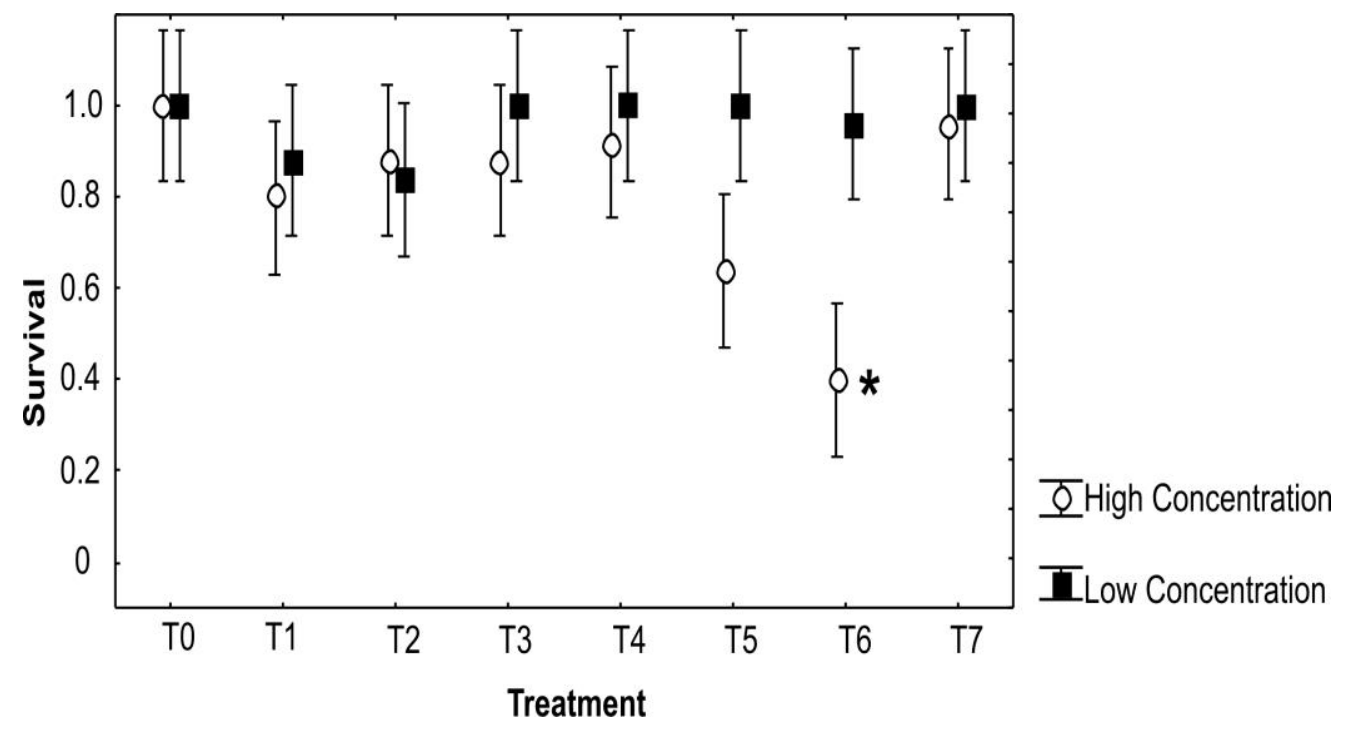

Figure 5. Effect of the different formulations tested and concentrations of surfactants on the survival of Sorghum halepense ranged from 0 to $100 \%(1.0)$ at 30 days measurement. $\left(^{*}\right)$ Denotes significant difference with the control (T0). Vertical bars denote $95 \%$ confidence intervals.

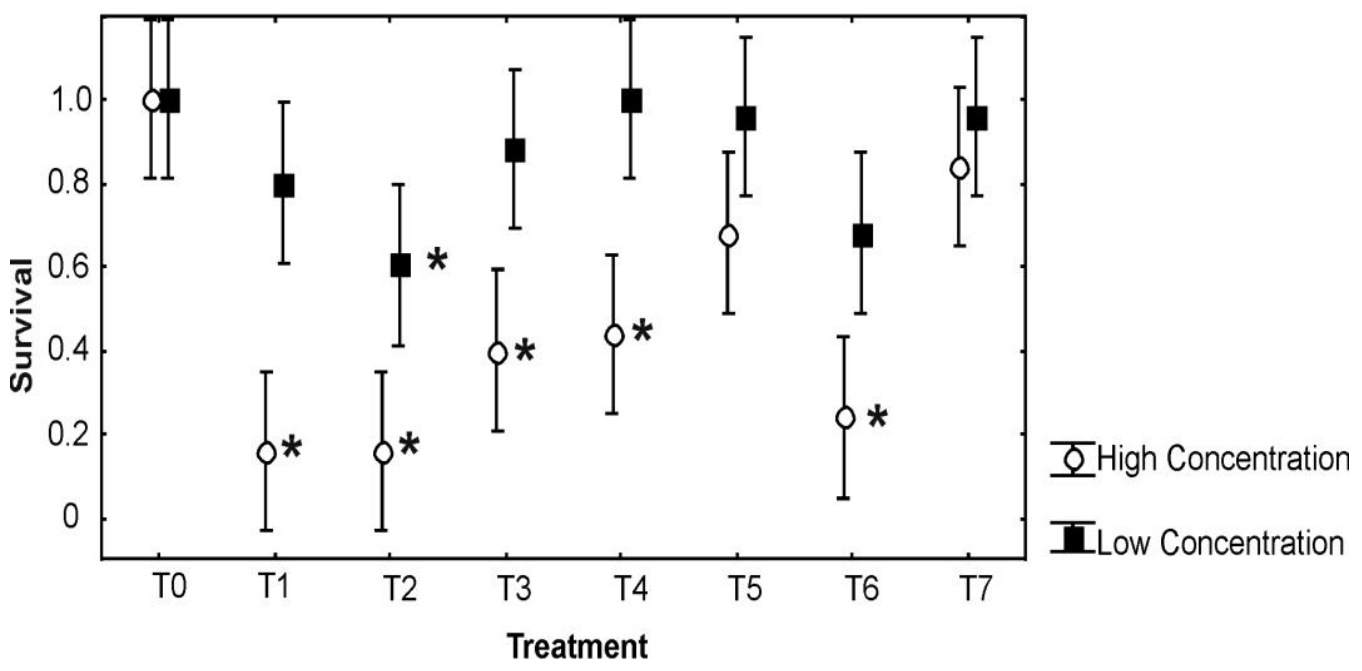

The field results at 15 days (Figure 4) showed that F5 is a significantly effective formulation at a high concentration. F5 showed no significant difference at the end of the study (30 days), either at high or low concentration. All formulations had the same effect on weeds at high doses. Without a surfactant, glyphosate cannot fulfill its herbicidal function as it must be sprayed on waxy leaves. On the other hand, T7 (Al) corroborates this since its results were equal to the control. The significant comparison between formulas occurred at low concentrations (Figure 5).

F2 proved to be the only effective formulation, as the rest of the formulations had no significant differences against the control. The results suggest that saponin is not needed in large amounts to improve glyphosate performance. The increase in saponin concentration in order of magnitude did not improve the herbicidal action, as observed when comparing F1 (T2) against F2 (T3). This is an important finding because it shows that low amounts of saponin achieve the desired effect, translating into a lower cost for formulations. 
The economic benefits of this work derive from the fact that a better uptake of the active principle allows a reduction in the amounts used of it. The use in surfactants of hydrophobic regions like cyclopentaneperhydrophenanthrene used in glyphosate formulations is not found in the available literature and results in a new scientific contribution. This work allows us to consider what other products of plant origin can be used or transformed for use in agrochemicals.

\section{CONCLUSION}

Our results allowed confirming that the use of saponin improves the herbicidal efficiency of glyphosate. Therefore, this can be a solution to reduce the environmental impact of formulations because the same effect can be obtained even if the amount of glyphosate applied is decreased. On the other hand, the surfactants used in this work (saponin and $A G$ ) are environmentally friendly, which further reduces the risk compared to formulations that still use POEA surfactants.

\section{ACKNOWLEDGEMENTS}

The authors would like to thank the Universidad de Buenos Aires for financial support through the UBACyT grants 20020150200063BA and 20020170200070BA, Prof. Ph.D. Alicia Fernández Cirelli, Ph.D. Mariano J.L. Castro, the anonymous reviewers for their constructive comments, which helped us to improve the work, and, finally, María Victoria Gonzalez Eusevi for grammar and spelling correction service.

\section{REFERENCES}

AYENI EA et al. 2021. Medicinal plants for anti-neurodegenerative diseases in West Africa. Journal of Ethnopharmacology 114468 Acesso em: 10 ago. 2011. In Press.

BEDNÁŘOVÁ A et al. 2020. The surfactant polyethoxylated tallowamine (POEA) reduces lifespan and inhibits fecundity in Drosophila melanogaster- In vivo and in vitro study. Ecotoxicology and Environmental Safety. 188: Article 109883.

BUCHBERGER G et al. 2018. Bio-inspired "fluidic diode" for large-area unidirectional passive water transport even against gravity. Sensors and Actuators A 283: 375-385.

CASTRO M et al. 2014. Advances in surfactants for agrochemicals. Environmental Chemistry Letters 12: 85-95.

CHAPAGAIN BP \& WIESMAN Z. 2004. Effect of Nutri-Vant-Peak foliar spray on plant development, yield and fruit quality in greenhouse tomatoes. Scientia Horticulturae 102: 177-188.

CHAPAGAIN BP \& WIESMAN Z. 2006. Phyto-Saponins as a Natural Adjuvant for Delivery of Agromaterials through Plant Cuticle Membranes. Journal of Agricultural and Food Chemistry 54: 6277-6285.

CORDEIRO GIUNCHETTI R et al. 2019. Canine visceral leishmaniasis biomarkers and their employment in vaccines. Veterinary Parasitology 271: 87-97.

DANNE $M$ et al. 2019. Analysing the importance of glyphosate as part of agricultural strategies: A discrete choice experiment. Land Use Policy 86: 189-207.

DI RIENZO JA et al. 2018. Infostat Centro de Transferencia InfoStat, FCA, Universidad Nacional de Córdoba, Argentina. Disponível em: http://www.infostat.com.ar. Acesso em: 6 set. 2018.

FERLIN N et al. 2008. Synthesis of sugar-based chelating surfactants for metal removal from wastewater. Carbohydrate Research 343: 839-847.

FERLIN N et al. 2010. Synthesis of new chelating surfactants from octyl D-glucopyranosiduronic acid and amino acids for metal flotation. Carbohydrate Research 345: 598-606.

FERLIN $N$ et al. 2015. Octyl glucoside derivatives: A tool against metal pollutants. Colloids and Surfaces A: Physicochemical and Engineering Aspects 480: 439-448.

GHARDE $Y$ et al. 2018. Assessment of yield and economic losses in agriculture due to weeds in India. Crop Protection 107: $12-18$.

HAOJING L et al. 2016. Foliar penetration enhanced by biosurfactant rhamnolipid. Colloids and Surfaces B: Biointerfaces 145: 548-554.

JOVANOVIC M et al. 2019. Rhamnolipid inspired lipopeptides effective in preventing adhesion and biofilm formation of Candida albicans. Bioorganic Chemistry 87: 209-217.

KLIJN ME \& HUBBUCH J. 2019. Correlating multidimensional short-term empirical protein properties to long-term protein physical stability data via empirical phase diagrams. International Journal of Pharmaceutics 560: 166-174.

KLIJN ME \& HUBBUCH J. 2019. Redesigning food protein formulations with empirical phase diagrams: A case study on glycerol-poor and glycerol-free formulations. Food Research International 125: 108609.

LINLIN Q et al. 2021. Protopanaxatriol-type saponin protects against acetaminophen-induced liver injury through ROSmediated JNK pathway. Journal of Functional Foods 86: 104672.

MERINO D \& ALVAREZ VA. 2021. Advanced applications of green materials in agriculture. In: WOODHEAD (Ed.) Applications of Advanced Green Materials. p.193-222.

MESNAGE R. 2021. 4 - Coformulants in commercial herbicides. Chemistry, Efficacy, Toxicology, and Environmental Impacts. Emerging Issues in Analytical Chemistry 87-111.

MO A et al. 2011. A heat shock protein based polyvalent vaccine targeting HSV-2: CD4+ and CD8+ cellular immunity 
and protective efficacy. Vaccine 29: 8530-8541.

PÉREZ M \& PÉREZ L. 2007-2008. Estrategias de control de malezas en maíz rg. Buenos Aires INTA EEA (Memoria técnica:41-43).

RIQUELME $\mathrm{N}$ et al. 2019. Physical stability of nanoemulsions with emulsifier mixtures: Replacement of tween 80 with Quillaja saponin. LWT - Food Science and Technology 111: 760-766.

SMIT WL et al. 2021. Translation initiation factor elF2B promotes Wnt-mediated clonogenicity and global translation in intestinal epithelial cells. Stem Cell Research. Acesso em: 10 ago. 2011.

WOJCIECHOWSKI K. 2013. Surface activity of saponin from Quillaja bark at the air/water and oil/water interfaces. Colloids and Surfaces B: Biointerfaces 108: 95-102.

ZAR JH. 2010. Biostatistical analysis. 4.ed. New Jersey: Prentice. 944p. 